INTERNATIONAL BULLETIN OF BACTERIOLOGICAL NOMENCLATURE AND TAXONOMY

Vol. 15, No. 2 ApriI 15, 1965

pp. $81-85$

\title{
CLARIFICATION OF THE IDENTIFICATION OF LYSENKO'S PROPOSED NEOTYPE STRAIN OF PSEUDOMONAS PSETDOMALLEI \\ (WHITMORE) HAYNES 1957
}

W. C. Haynes

Northern Utilization Research and Development Division U.S. Department of Agriculture, Peoria, Illinois

SUMMARY. Lysenko (1961) cited CCEB 472 (NRRL $B-12)$ to identify the strain he proposed as neotype for Pseudomonas pseudomallei (Whitmore) Haynes 1957. He thus incorrectly signified that CCEB 472 and NRRL B-1 2 are different designations of the same strain. In fact, they are strain numbers of two different microorganisms. The correct citation is CCEB 472 (NRRL B-1112). The error has been perpetuated and compounded in recent catalogues of the Culture Collection of. Entomogenous Bacteria, of the Czechoslovak Collections of Microorganisms, and inadvertently of the American Type Culture Collection. Histories of the confounded strains are presented and the relationships among the accession numbers in various culture collections are shown as aids in untangling the confusion that has developed.

In 1961 Lysenko proposed CCEB 472 (NRRL B-12) as the neotype strain of Pseudomonas pseudomallei (Whitmore) Haynes 1957. This seemed an anomalous proposal for the following reasons:

1. NRRL B-12, identified by Haynes (1951) as an apyocyanogenic strain of $P$. aeruginosa, has been distributed under no other name from the ARS Culture Collection.

2. Lysenko's characterization of $P$. pseudomallei differs in several respects from Haynes' characterization of NRRL $\mathrm{B}-12$.

3. According to records of the ARS Culture Collection, NRRL B-12 never was sent to Lysenko. 
4. The records show that Iysenko was sent $\underline{P}$. pseudomallei NRRL B-11I2. The se observations raised suspicion that a mistake had been made. Correspondence with Lysenko revealed that this was indeed the case.

Before the error was detected, it was compounded by repetition in the 1963 catalogue of the Culture Collection of Entomogenous Bacteria (CCEB, Prague, Czechoslovakia) in which a similar error was made in respect to CCEB 471 , another strain of $\underline{P}$. pseudomallei, which is cited as equivalent to NRRL B- $\overline{10}$ instead of NRRL B-1110. In the 1964 Catalogue of Cultures of the Czechoslovak Collections of Microorganisms (CCM, Brno, Czechoslovakia) the same errors appeared.

The mistake was inadvertently further compounded in the 1964 edition of the Catalogue of Cultures of the American Type Culture Collection (ATCC, Washington, D. C., U.S. A.). In it, the erroneous NRRL B-12 synonym for CCEB 472 is reconverted to $A T C C I 42$, the number under which NRRL B-12 was received by the ARS Culture Collection in 1940 . On page 88 of the Catalogue,ATCC 142 is:

1. Improperly listed under the name $\underline{\mathrm{P}} \cdot$ pseudomallei (Whitmore) Haynes.

2. Alleged to be the suggested neotype of $\underline{P}$. pseudomallei and Lysenko's proposal is cited to support the allegation.

3. Erroneously considered to be synonymous with CCEB 472 and NRRL B-1112.

A further complication is brought about by listing ATCC 142 also on page 85 , this time under the name $P$. fluorescens. Again the designations CCEB 472 and NRRL B-1112 are given erroneously as equivalent to ATCC 142 and comments are added implying that this is the strain proposed as the neotype for $\underline{P}$. pseudomallei.

The relationships among the various strains and their numbers have become so confused that a clarification is needed. Table 1 shows the correct relationships. Table 2 presents the histories of the four strains involved.

In summary, the tables show that the correct citation to Lysenko's proposed neotype is P. pseudomallei CCEB 472 (NRRL B-1112). This change should be incorporated in his proposal, in the 1963 Catalogue of the Culture Collection of 
BACTERIOLOGICAL NOMENCLATURE AND TAXONOMY

Table 1. Corresponding accession numbers of confounded strains.

\begin{tabular}{|c|c|c|c|c|}
\hline $\begin{array}{l}\text { NRRL }^{+} \\
\text {number }\end{array}$ & $\begin{array}{l}\text { ATCC } \\
\text { number }\end{array}$ & $\begin{array}{l}\text { NCTC } \\
\text { number }\end{array}$ & $\begin{array}{l}\text { CCEB } \\
\text { number }\end{array}$ & $\begin{array}{c}\text { Name in ARS } \\
\text { Culture Collection }\end{array}$ \\
\hline$B-10$ & 948 & & $*$ & P. fluorescens \\
\hline$B-12$ & $142 * 2$ & & F米净 & $\bar{P} \cdot$ aeruginosa \\
\hline$B-1110$ & & 1688 & $\overline{471}$ & $\overline{\mathbf{P}} \cdot \overline{\text { pseudomallei }}$ \\
\hline$B-1112$ & $\overline{15682}$ & 4845 & 472 & $\vec{P} \cdot$ pseudomallei \\
\hline
\end{tabular}

*Erroneously identified as $\underline{\text { P. pseudomallei CCEB } 471 \text { in }}$ 1963 Catalogue of the $C C E B$, page 26, and the 1964 Catalogue of Cultures of the CCM, page 74 .

**Erroneously identified as CCEB 472 and NRRL B-1112 in the 1964 Catalogue of Cultures of the American Type Culture Collection, pages 85 and 88 .

***Erroneously identified as CCEB 472 in 1963 Catalogue of the Culture Collection of Entomogenous Bacteria, page 26, in Jour. Gen. Microbiol. 25(3):399-400, 1961; and in the 1964 Catalogue of Cultures of the Czechoslovak Collections of Microorganisms, page 74 .

tThe letters NRRL, ATCC, NCTC and CCEB precede strain numbers in the ARS Culture Collection (NRRL means Northern Regional Research Laboratory, the name of the institution that houses the ARS Culture Collection); the American Type Culture Collection; the National Collection of Type Cultures; and the Culture Collection of Entomogenous Bacteria, respectively. 
Table 2. Correct histories of confounded strains.

NRRL B-10: Received in 1940 from the ATCC as $\underline{P}$. fluorescens 948. ATCC obtained it in 1926 from Max Levine as culture number 1013.

NRRL B-12: $\quad$ Received in 1940 from the ATCC as $\underline{P}$. fluorescens 142. Incorporated in the newly formed ATCC in 1925 from the Army Medical Museum. Reidentified as an apyocyanogenic strain of $\underline{P}$. ae ruginosa by Haynes (1951).

NRRL B-1110: Received in 1950 from the NCTC as Pfeifferella* pseudomallei 1688 . In a paper by Brindle and Cowan (1951) it was designated "Rat" and was said to have been isolated by Stanton and Fletcher from melioidosis in a rat.

NRRL B-1112: Received in 1950 from the NCTC as Pfeifferella* pseudomallei 4845. In Brindle and Cowan (195I) it was designated S. 397 and was said to have been isolated in 1935 from a monkey in Singapore.

*In the 7th edition of Bergey's Manual (1957) the species has been reassigned to the genus Pseudomonas as Pseudomonas pseudomallei. 
BACTERIOLOGICAL NOMENCLATURE AND TAXONOMY

Entomogenous Bacteria and in the 1964 Catalogue of Cultures of the Czechoslovak Collections of Microorganisms. In the two catalogues, also, CCEB 471 P. pseudomallei should be changed to show that it originated from NRRL B-I110, not NRRL B-10.

In the 1964 edition of the Catalogue of Cultures of the American Type Culture Collection, all reference to ATCC 142 being a strain of $\underline{P}$. pseudomallei with equivalence to CCEB 472 and NRRL B-1112 should be disregarded. In undistributed catalogues, the appropriate changes should be made.

NRRL B-II 12 has been deposited in the American Type Culture Collection to serve as a representative of the proposed neotype of $\underline{P}$. pseudomallei. The ATCC number is 15682 .

\section{REFERENCES}

Breed, R.S., E. G. D. Murray, and N. R. Smith. 1957. Bergey's Manual of Determinative Bacteriology. 7 th ed. Williams and Wilkins Co., Baltimore, Maryland.

Brindle, C.S. and S. T. Cowan. 1951. Flagellation and taxonomy of Whitmore's bacillus. Jour. Path. Bact. 63:571-575.

Haynes, W. C. 1951. Pseudomonas aeruginosa-its characterization and identification. Jour. Gen. Microbiol. 5:939-950.

Lysenko, O. 1961. Pseudomonas-An attempt at a general classification. Jour. Gen. Microbiol. 25:379-408. 
